\title{
EKSPERIMENTASI PEMBELAJARAN MATEMATIKA DENGAN MODEL PEMBELAJARAN KOOPERATIF TIPE TEAMS GAMES TOURNAMENTS (TGT) DAN TEAMS ASSISTED INDIVIDUALIZATION (TAI) PADA MATERI POKOK BANGUN RUANG SISI DATAR DITINJAU DARI MOTIVASI BERPRESTASI SISWA KELAS VIII SMP NEGERI SE-KABUPATEN WONOGIRI
}

\author{
Mishbahul Huda $^{1}$, Tri Atmojo Kusmayadi ${ }^{2}$, Budi Usodo ${ }^{3}$ \\ ${ }^{1,2,3}$ Prodi Magister Pendidikan Matematika, FKIP Universitas Sebelas Maret Surakarta
}

\begin{abstract}
The objectives of this research are to investigate: (1) which learning model of the cooperative learning model of the TGT type, the cooperative learning model of the TAI type, and the direc learning model results in a better learning achievement in Mathematics; (2) which students of the the students with the high achievement motivation, the students with the moderate achievement motivation, and the students with the low achievement motivation have a better learning achievement in Mathematics; (3) in each category of the achievement motivations, which learning model of the cooperative learning model of the TGT type, the cooperative learning model of the TAI type, and the direc learning model results in a better learning achievement in Mathematics; and (4) in each learning model, which students of the the students with the high achievement motivation, the students with the moderate achievement motivation, and the students with the low achievement motivation have a better learning achievement in Mathematics. This research used the quasi experimental research method with the factorial design of $3 \times 3$. Its population was the students in Grade VIII of State Junior Secondary Schools of Wonogiri regency in Academic Year 2013/2014. The samples of the research were taken by using the stratified cluster random sampling technique. The samples of the research were the students as many as 299 of State Junior Secondary School 1 of Purwantoro, State Junior Secondary School 1 of Jatisrono, and State Junior Secondary School 2 Puhpelem. The data of the research were analyzed by using the two-way analysis of variance (ANOVA) with unbalanced cells at the significance level of 5\%. The results of the research are as follows: 1) the students instructed with the cooperative learning model of the TGT type have a better learning achievement in Mathematics as those instructed with the cooperative learning model of the TAI type and direct learning model, the students instructed with the cooperative learning model of the TAI type have a better learning achievement in Mathematics as those instructed with the direct learning model. 2) The students with the high achievement motivation have a better learning achievement in Mathematics as those with the moderate achievement motivation and low achievement motivation, the students with the high achievement motivation have a better learning achievement in Mathematics than those with the low achievement motivation. 3) In each category of the achievement motivations, the students instructed with the cooperative learning model of the TGT type have a better learning achievement in Mathematics as those instructed with the cooperative learning model of the TAI type and direct learning model, the students instructed with the cooperative learning model of the TAI type have a better learning achievement in Mathematics as those instructed with the direct learning model. 4) In each learning model, the students with the high achievement motivation have a better learning achievement in Mathematics as those with the moderate achievement motivation and low achievement motivation, the students with the moderate achievement motivation have a better learning achievement in Mathematics as those with the low achievement motivation.
\end{abstract}

Keywords: The cooperative learning model of the TGT type, the cooperative learning model of the TAI type, direct learning, and achievement motivation. 


\section{PENDAHULUAN}

Menurut UU RI Nomor 20 tahun 2003 tentang Sistem Pendidikan Nasional, dalam pasal 1 yang dimaksud dengan "Pembelajaran adalah proses interaksi peserta didik dengan pendidik dan sumber belajar pada suatu lingkungan belajar". Dalam pasal yang sama juga dijelaskan bahwa "peserta didik adalah anggota masyarakat yang berusaha mengembangkan potensi diri melalui proses pembelajaran yang tersedia pada jalur, jenjang, dan jenis pendidikan tertentu" dan "pendidik adalah tenaga kependidikan yang berkualifikasi sebagai guru, dosen, konselor, pamong belajar, widyaswara, tutor, istruktur, fasilitator, dan sebutan lain yang sesuai dengan kekhususannya, serta berpartisipasi dalam menyelenggarakan pendidikan”.

Pembelajaran merupakan interaksi sistematis antara peserta didik dengan pendidik yang berkaitan dengan materi pembelajaran pada suatu lingkungan belajar. Kegiatan pembelajaran memberdayakan semua potensi peserta didik untuk menguasai kompetensi yang diharapkan. Menurut Nurhadi (2004:30) kegiatan pembelajaran perlu berpusat pada peserta didik dengan menciptakan kondisi yang menyenangkan dan menantang untuk mengembangkan kreativitas peserta didik dan menyedikan pengalaman belajar yang beragam, pembelajaran juga bermuatan nilai, etika, estetika, logika dan kinestika.

Berhasil atau tidaknya pembelajaran tergantung pada guru dan peserta didik sebagai aktor dalam pembelajaran. Guru adalah salah satu unsur dalam pembelajaran yang ikut berperan dalam usaha pembentukan sumber daya manusia yang potensial di bidang pembangunan. Oleh karena itu guru merupakan salah satu unsur di bidang pendidikan secara aktif dan menempatkan kedudukannya sebagai tenaga professional, sesuai dengan tuntutan masyarakat yang semakin berkembang (Sardiman, 2001:125).

Matematika merupakan salah satu ilmu pengetahuan yang memegang peranan penting dalam meningkatkan kualitas sumber daya manusia. Namun banyak siswa menganggap matematika sebagai pelajaran yang menakutkan, sehingga hasil pembelajaran siswa tidak sesuai dengan yang diharapkan. Nilai matematika yang diperoleh oleh siswa cenderung lebih rendah jika dibandingkan dengan mata pelajaran yang lain. Dari hasil ujian nasional tahun pelajaran 2012/2013 pada jenjang SMP/MTs mata pelajaran matematika memperoleh nilai rata-rata 5,78 Bahasa Indonesia memperoleh nilai rata-rata 6,93 bahasa inggris mempunyai nilai rata-rata 5,90 sedangkan IPA mempunyai nilai rata-rata 5,99 (Balitbang Kemdikbud, 2013). Hal ini menunjukkan bahwa nilai matematika dalam ujian nasional di tingkat nasional masih rendah.

Secara lebih spesifik, permasalahan pembelajaran matematika juga terjadi di sekolah-sekolah Kabupaten Wonogiri. Dari data hasil Ujian Nasional pada tingkat 
SMP/MTs tahun pelajaran 2012/2013 di Kota Wonogiri menunjukkan mata pelajaran matematika memperoleh nilai rata-rata 4,93 bahasa indonesia memperoleh nilai ratarata 7,91 bahasa inggris mempunyai nilai rata-rata 5,22 sedangkan ipa mempunyai nilai rata-rata 5,61 (Balitbang Kemdikbud, 2013). Hal ini menunjukkan bahwa nilai ujian nasional matematika di Indonesia terutama di Kabupaten Wonogiri masih yang paling rendah.

Dalam penelitian ini, penulis mengambil materi dasar bangun ruang sisi datar karena penulis melihat data pada ujian nasional jenjang SMP/MTs tahun 2012/2013 menunjukkan bahwa pada materi tersebut nilai rata-rata anak yang menjawab benar di kabupaten Wonogiri hanya 44,48\%. Hal ini mengindikasikan ada permasalahan dalam materi tersebut. Oleh karena itu penulis mengkaji lebih lanjut permasalahan yang ada pada materi bangun ruang sisi datar.

Ada beberapa model pembelajaran, diantaranya model pembelajaran konstektual, model pembelajaran direct instruction, model pembelajaran berbasis masalah, model pembelajaran kooperatif dan lain-lain. Pada penelitian ini digunakan model pembelajaran kooperatif, model pembelajaran kooperatif belum banyak digunakan dalam pendidikan walaupun orang Indonesia sangat membanggakan sifat gotong royong dalam kehidupan bermasyarakat. Pembelajaran kooperatif mulai banyak digunakan di sekolah- sekolah sebagai salah satu model pembelajaran untuk meningkatkan mutu pembelajaran.

"Co-operative learning is characterized by positive interdependence with structured goals, a clear accountability for individual's share of the group's work through role assisment and regular rotation of the assigned role, heterogeneous ability grouping, sharing of leadership roles, sharing of the appointed learning task, aiming to maximize each member's learning, maintaining good working relationship, process-orientation, teaching of collaborative skills, teacher observation of studen's interaction and structuring of the procedures and time for the processing." (Pandya,2011)

Model pembelajaran kooperatif mempunyai karakter positive interdepence, interaction face to face, adanya tanggung jawab pribadi tentang materi pelajaran dalam, kelompok, membutuhkan keluwesan dan memelihara hubungan kerja yang efektif, serta bekerjasama dalam memecahkan masalah. Pada model pembelajaran kooperatif ada beberapa tipe diantaranya jigsaw, Game Investigation (GI), Student Teams Achievement Division (STAD), Teams Assisted Individualization (TAI), Two Stay Two Stray (TSTS), Teams Games Tournament (TGT), Numbered Heads Together (NHT). Penelitian ini menggunakan model pembelajaran kooperatif tipe teams games tournament (TGT) dan teams assisted individualization (TAI). 
Menurut Gisbert, at al (2008:481) bahwa "using curricular competence improvement as a control, show an increase in self-concept as a writer for all students who were given the opportunity to act as tutors, either in fixed or in reciprocal role tutoring. Only fixed tutees, but not reciprocal tutees, feel more satisfied with their peer tutors than with the teacher 's help". Dari pernyataan itu dapat diambil kesimpulan bahwa peran tutor teman sebaya sangat berarti dalam meningkatkan prestasi belajar. Adanya tutor sebaya ini dapat dijumpai dalam model pembelajaran kooperatif tipe TGT dan TAI.

Shimazoe dan Aldrich (2010) menyatakan : "In cooperative learning instruction focuses on coordinating stimulations an encouraring interaction amongs students with student expected to learn from their own activities and interaction with their peers" dalam pembelajaran kooperatif pengajaran berfokus pada mengkoordinasikan, merangsang dan mendorong interaksi antara siswa dengan harapan belajar siswa dari kegiatan-kegiatan dan interaksi dengan teman-temannya.

Ada beberapa alasan mengapa peneliti membandingkan antara model pembelajaran kooperatif tipe TGT dan tipe TAI untuk materi pokok bangun ruang sisi datar yakni: (1) Pada model pembelajaran kooperatif tipe TGT adanya usaha untuk memotivasi peserta didik supaya dapat saling mendukung dan membantu satu sama lain dalam menguasai kemampuan yang diajarkan oleh guru. (2) Pada model pembelajaran kooperatif tipe TGT menggunakan pola pengajaran tunggal untuk satu kelas sedangkan pada tipe TAI menggabungkan pembelajaran kooperatif dengan pembelajaran yang individual. (3) Model pembelajaran tersebut member peluang kepada peserta didik yang berbeda latar belakang dan kondisi untuk bekerja saling bergantung atas tugas-tugas bersama, dan melalui penggunaan struktur penghargaan belajar untuk menghargai satu sama lain. (4) Kedua model pembelajaran tersebut mempunyai banyak persamaan dalam hal belajar bersama, penghargaan kelompok, dan dalam mencapai sukses bersama. (5) Model pembelajaran tersebut dapat membuat peserta didik mengolah semua informasi yang ada dengan menggunakan pengetahuan yang telah dimilikinya. (6) Model pembelajaran tersebut dapat diaplikasikan pada hampir semua mata pelajaran dan tingkat kelas.

Model pembelajaran kooperatif tipe TGT adalah model manajemen kelas dimana para peserta didik ditempatkan dalam tim dengan kemampuan yang heterogen untuk berkompetisi dalam sebuah permainan. Menurut Slavin (2008), TGT dapat meningkatkan kemampuan dasar, prestasi belajar peserta didik, interaksi positif antar peserta didik, penerimaan keanekaragaman teman sekelas dan kepercayaan diri. Pada model pembelajaran ini peserta didik menjadi siap dan berusaha untuk memahami dan 
menguasai materi yang sedang disampaikan oleh guru dalam proses pembelajaran dan melatih peserta didik untuk bekerjasama dengan baik dengan anggota kelompoknya dalam menjawab tugas yang diberikan oleh guru. TGT mempunyai 3 elemen dasar: (1) teams - peserta didik ditempatkatkan ke dalam tim-tim dengan kemampuan heterogen, (2) games-latihan kemampuan dimainkan selama tournament mingguan, (3) tournament - peserta didik mewakili timnya dan berkompetisi secara individual melawan peserta didik yang berasal dari tim-tim lain. Dengan TGT peserta didik diharapkan lebih tertarik dalam materi pelajaran, karena pelajaran disampaikan dengan cara yang lebih menyenangkan dan menarik.

Selain TGT, alternatif model pembelajaran yang dapat digunakan adalah TAI. Dalam pembelajaran kooperatif tipe TAI peserta didik lebih mendorong dan membantu satu sama lain untuk bekerja keras karena ingin kelompok mereka berhasil. Tanggung jawab individu terjamin karena hanya menilai jumlah dari skor tes akhir dan peserta didik mengerjakan tes akhir tanpa bantuan anggota kelompok. Peserta didik memiliki kesemptan yang sama untuk berhasil, karena semua telah ditempatkan menurut tingkat pengetahuan mereka sebelumnya.

Pada pembelajaran dengan menggunakan tipe TAI, peserta didik bekerja pada level mereka sendiri, sehingga mereka tidak cukup mampu pada kemampuan awal, mereka terlebih dahulu membangun pondasi yang kuat sebelum melangkah lebih lanjut. Sebaliknya jika peserta didik dapat berkembang lebih cepat, mereka tidak harus menunggu sampai selesai. Pembelajaran kooperatif tipe TGT dan TAI menekankan kerjasama dan saling tukar pengetahuan, maka partisipasi aktif individu dalam setiap kelompok sangat diharapkan peserta didik yang mempunyai kemampuan berfikir tinggi untuk dapat membantu peserta didik lain yang mengalami kesulitan belajar sehingga semua peserta didik mendapatkan kemampuan yang optimal.

Upaya yang penulis lakukan adalah mengubah metode yang pada awalnya menggunakan metode ceramah dan diskusi informasi menjadi strategi mengajar menggunakan pembelajaran kooperatif tipe TGT dan TAI yang diharapkan dapat meningkatkan hasil belajar peserta didik. Dalam penelitian ini penulis ingin menyelidiki pengaruh motivasi berprestasi terhadap hasil belajar peserta didik. Pengertian dasar motivasi adalah keadaan organisme baik manusia maupun hewan yang mendorong untuk berbuat sesuatu. Dalam pengertian ini, motivasi berarti pemasok daya (energizer) untuk bertingkah laku secara terarah menyatakan bahwa motivasi belajar adalah keseluruhan daya peggerak psikis dalam diri siswa yang menimbulkan kemampuan untuk 
melaksanakan kegiatan belajar dan menjamin kelangsungan belajar itu demi untuk mencapai tujuan.

Menurut Arend (1998;76) "motivation is usually bdefined as the processeswithin individual that stimulate behavior or arouse us to take action". Motivasi didefinisikan sebagai proses dalam individu-individu yang mendorong tingkah laku atau menggerakan seseorang untuk melakukan tindakan. Senada dengan definisi tersebut. Ngalim Purwanto $(1990 ; 71)$ menyatakan "motivasi adalah pendorong suatau usaha yang didasari untuk mempengaruhi tingkah laku seseorang agar dia tergerak hatinya untuk bertindak untuk melakukan sesuatu sehingga mencapai hasil atau tujuan tertentu".

Motivasi berprestasi dapat mempengaruhi adanya kegiatan yang dilakukan, sehubungan dengan hal tersebut, motivasi berprestasi dapat berfungsi untuk: 1) Mendorong manusia berbuat, dengan kata lain motivasi sebagai motor penggerak yang melepaskan energi. 2) Menentukan arah perbuatan, maksudnya adalah untuk mencapai tujuan yang hendak dicapai. 3) Menyeleksi perbuatan, maksudnya adalah untuk menentukan perbuatan-perbuatan apa yang harus dikerjakan guna mencapai tujuan dengan menghindari perbuatan yang tidak bermanfaat.

Dikaitkan dengan kegiatan belajar motivasi ditinjau dari segi potensi dapat berupa sikap sedangkan penampakannya berupa perilaku belajar. Adapun pengertian belajar menurut (Sardiman, 2001:21) adalah " sebagai rangkaian kegiatan jiwa raga, psikofisik untuk menuju ke arah perkembangan pribadi manusia seutuhnya, yaitu menyangkut unsur cipta, rasa dan karsa dalam ranah kognitif, efektif , psikomotor. Jadi motivasi dapat disimpulkan dorongan-dorongan untuk menggerakkan seseorang dalam melakukan tindakan berbuat sesuatu dan akan mempengartuhi tingkah laku. Motivasi merupakan perilaku atau tindakan yang akan menentukan kebutuhan (needs) atau wujud perilaku mencapai tujuan, jika seorang siswa termotivasi untuk mendapatkan sesuatu (prestasi yang memuaskan), maka siswa akan memenuhi kebutuhan (needs) tersebut.

Setiap karakter yang melekat dalam diri seseorang memiliki ciri khas yang ditampilkan dalam aktivitasnya, hal ini juga motivasi berprestasi. Keller, Kelly, \& Dodge dalam Degeng (1997:41) menyimpulkan ada 6 karakteristik motivasi berprestasi individu yang nampak konsisten ditemukan dalam konteks sekolah: 1) individu yang memiliki motivasi berprestasi tinggi lebih menyukai terlibat dalam situasi di mana ada resiko gagal, atau lebih menyukai keberhasilan yang penuh dengan tantangan. Sebaliknya individu yang memiliki motivasi berprestasi rendah cenderung memilih tugas-tugas yang memiliki peluang besar untuk berhasil atau yang tidak mungkin berhasil. Hal ini dilakukan untuk menghindari rasa kecemasan. 2) faktor kunci yang memotivasi individu 
berprestasi tinggi adalah kepuasan instrinsik dan keberhasilan itu sendiri, bukan pada ganjaran ekstrinsik seperti uang, kedudukan. 3) individu yang memliki motivasi berprestasi tinggi cenderung membuat pilihan atau tindakan yang realistis dalam menyelesaikan tugas-tugasnya sesuai dengan kemampuannya, 4) individu yang memiliki motivasi berprestasi tinggi menyukai situasi di mana ia dapat menilai sendiri kemajuan dan pencapaian tujuannya (kontrol pribadi), 5) memiliki perspektif waktu jauh ke depan, ia berkeyakinan bahwa waktu berjalan dengan cepat, sehingga waktu sangat berharga. 6) tidak selalu menunjukkan rata-rata nilai yang tinggi di sekolahnya. Ini mungkin disebabkan nilai di sekolah banyak terkait dengan motivasi ekstrinsik. Atas dasar tersebut, maka dapat dirumuskan bahwa tidak selalu ditemukan ada korelasi yang tinggi antara nilai dengan motivasi berprestasi.

Degeng (1997) mengemukakan bahwa motivasi berprestasi disebut tinggi apabila keinginan untuk sukses lebih besar daripada ketakutan pada kegagalan. Lebih lanjut Atkinson menyatakan bahwa seseorang yang memiliki motivasi berprestasi tinggi memiliki ciri-ciri sebagai berikut: 1) memiliki tanggung jawab yang tinggi pada tugasnya, 2) menetapkan tujuan yang menantang, sulit dan realistik, 3) memiliki harapan sukses, 4) melakukan usaha yang keras untuk mencapai kesuksesan, 5) tidak memikirkan kegagalan, 6) berusaha memperoleh hasil yang terbaik. Dalam kegiatan pembelajaran, motivasi berprestasi hendaknya diperhatikan oleh guru sebagai upaya memperoleh hasil belajar yang optimal.

Tujuan penelitian adalah (1) Untuk mengetahui diantara pembalajaran kooperatif TGT, teams TAI, atau pembelajaran langsung yang memberikan prestasi belajar lebih baik pada materi pokok bangun ruang sisi datar; (2) Manakah diantara tipe motivasi berprestasi tinggi, sedang dan rendah yang memberikan prestasi belajar lebih baik; (3) Pada masing-masing model pembelajaran kooperatif tipe TGT, TAI atau pembelajaran langsung, manakah tipe motivasi berprestasi tinggi, sedang dan rendah yang memberikan prestasi belajar lebih baik pada materi pokok bangun ruang sisi datar; (4) Pada masingmasing tipe motivasi berprestasi tinggi, motivasi berprestasi sedang dan motivasi berprestasi rendah, manakah model pembelajaran yang memberikan prestasi belajar lebih baik pada materi pokok bangun ruang sisi datar.

\section{METODE PENELITIAN}

Penelitian ini merupakan penelitian eksperimental semu dengan desain faktorial 3x3. Populasi penelitian adalah semua siswa kelas VIII SMP Negeri di Kabupaten Wonogiri tahun pelajaran 2013/2014. Penelitian dilakukan di SMP Negeri 1 
Purwantoro, SMP Negeri 1 Jatisrono, dan SMP Negeri 2 Puhpelem dengan ukuran sampel 299 siswa. Dari masing-masing sekolah diambil tiga kelas secara acak, masingmasing satu kelas eksperimen model pembelajaran kooperatif tipe TGT, satu kelas eksperimen model model pembelajaran kooperatif tipe TAI dan satu kelas kontrol model pembelajaran langsung. Analisis data dilakukan dengan Anava dua jalan dengan sel tak sama dengan taraf signifikansi $5 \%$.

Uji normalitas menggunakan metode Lilliefors dan diperoleh hasil bahwa ketiga kelompok berasal dari populasi yang berdistribusi normal. Uji homogenitas menggunakan uji Bartlett, diperoleh hasil bahwa ketiga kelompok mempunyai variansi homogen $\left(\chi^{2}\right.$ Observasi $=0,0140<5,9910=\chi^{2}$ tabel). Uji keseimbangan kemampuan awal menggunakan anava satu jalan dan diperoleh $F_{\text {obs }}=0,0711<3,0000=F_{\text {tabel. }}$. Hal ini menunjukkan bahwa ketiga populasi memiliki kemampuan awal yang sama atau seimbang.

Variabel terikat dalam penelitian ini adalah prestasi belajar matematika pada pokok bahasan bangun ruang sisi datar, sedangkan variabel bebasnya ada dua yaitu model pembelajaran yang terbagi atas model pembelajaran kooperatif tipe TGT pada kelas eksperimen pertama, model pembelajaran kooperatif tipe TAI pada kelas eksperimen kedua, dan model pembelajaran langsung pada kelas kontrol dan motivasi berprestasi siswa yang terbagi menjadi motivasi berprestasi tinggi, sedang dan rendah.

Uji coba instrumen tes prestasi dilakukan di SMP Negeri 2 Bulukerto dengan responden 96 siswa kelas IX. Untuk instrumen tes prestasi belajar, mengacu pada kriteria yaitu validitas isi, daya pembeda ( $\mathrm{D} \geq 0,3)$, tingkat kesukaran $(0,30 \leq P \leq 0,7)$, dan reliabilitas $\left(r_{x y}>0,70\right)$ dan instrumen angket gaya belajar siswa mengacu pada kriteria yaitu validitas isi, konsistensi internal $(\mathrm{KI} \geq 0,3)$, dan reliabilitas $\left(r_{x y}>0,70\right)$. Dari 35 butir soal tes prestasi yang diujicobakan diperoleh 23 butir soal yang baik. Namun ditetapkan 20 butir soal yang digunakan sebagai instrumen penelitian tes prestasi belajar matematika siswa. Untuk angket. Dari hasil penghitungan konsistensi internal diperoleh bahwa pada angket motivasi berprestasi terdapat 30 butir soal yang dapat digunakan. Selanjutnya dari angket motivasi berprestasi diambil 30 butir soal yang mewakili masingmasing indikator yang tertuang dalam kisi-kisi penyusunan butir soal, yang akan dipakai sebagai instrumen angket motivasi berprestasi dan reliabilitas yang baik. Uji prasyarat analisis yaitu uji normalitas dengan metode Lilliefors dan uji homogenitas dengan uji Bartlett. Diperoleh prasyarat normalitas dan homogenitas data telah terpenuhi, sehingga dapat dilakukan analisis data menggunakan anava dua jalan dengan sel tak sama dan uji komparasi ganda menggunakan metode Scheffe'. 


\section{HASIL PENELITIAN DAN PEMBAHASAN}

Hasil rataan masing-masing sel dan rataan marginal prestasi belajar matematika siswa disajikan dalam Tabel 1.

Tabel 1 Rataan Masing-masing Sel dan Rataan Marginal

\begin{tabular}{ccccc}
\hline Motivasi berprestasi (B) & $\begin{array}{c}\text { Tinggi } \\
\text { (B1) }\end{array}$ & $\begin{array}{c}\text { Sedang } \\
(\mathrm{B} 2)\end{array}$ & $\begin{array}{c}\text { Rendah } \\
\text { (B3) }\end{array}$ & $\begin{array}{c}\text { Rataan } \\
\text { Marginal }\end{array}$ \\
\hline TGT (A1) & 6.9459 & 6.3289 & 5.9400 & 6.4600 \\
\hline TAI (A2) & 6.4516 & 5.6471 & 4.8714 & 5.6600 \\
\hline Langsung (A3) & 5.1071 & 5.0147 & 4.6081 & 4.8889 \\
\hline Rataan Marginal & 6.2500 & 5.6887 & 5.0825 & \\
\hline Ringkasan hasil analisis variansi dua jalan dengan sel tak sama disajikan dalam Tabel 2.
\end{tabular}

Tabel 2 Rangkuman Hasil Analisis Variansi Dua Jalan dengan Sel Tak Sama

\begin{tabular}{lrcrccc}
\hline \multicolumn{1}{c}{ Sumber } & \multicolumn{1}{c}{$\mathrm{JK}$} & $\mathrm{dK}$ & $\mathrm{RK}$ & $F_{\text {obs }}$ & $F_{\text {tabel }}$ & Keputusan \\
\hline Model Pembelajaran (A) & 109.4922 & 2 & 54.7461 & 23.4825 & 3.00 & $\mathrm{H}_{0 \mathrm{~A}}$ ditolak \\
\hline Motivasi berprestasi (B) & 48.4800 & 2 & 24.2400 & 10.3974 & 3.00 & $\mathrm{H}_{0 \mathrm{~B}}$ ditolak \\
\hline Interaksi (AB) & 8.7650 & 4 & 2.1913 & 0.9399 & 2.40 & $\mathrm{H}_{0 \mathrm{AB}}$ diterima \\
\hline Galat & 676.0924 & 290 & 2.3314 \\
\hline Total & 842.8296 & 298 \\
\hline \multicolumn{7}{c}{ Dari Tabel 2 dapat dilihat bahwa $\mathrm{H}_{\mathrm{OA}}$ ditolak, $\mathrm{H}_{\mathrm{OB}}$ ditolak, dan $\mathrm{H}_{\mathrm{OAB}}$ diterima. }
\end{tabular}

Dengan demikian dapat disimpulkan : (1) Siswa-siswa yang mendapat pembelajaran kooperatif tipe TGT dan siswa-siswa yang mendapat pembelajaran kooperatif tipe TAI serta siswa-siswa yang mendapat pembelajaran langsung mempunyai prestasi belajar yang berbeda. (2) Siswa-siswa dengan motivasi berprestasi tinggi, siswa-siswa dengan motivasi berprestasi sedang, dan siswa-siswa dengan motivasi berprestasi rendah mempunyai prestasi belajar yang berbeda. (3) Tidak terdapat interaksi antara model pembelajaran dan motivasi berprestasi siswa terhadap prestasi belajar matematika pada pokok bahasan bangun ruang sisi datar.

\section{Tabel 3 Hasil Uji Komparasi Ganda Antar Baris}

\begin{tabular}{ccccc}
\hline Komparasi & $\mathrm{H}_{\mathrm{o}}$ & $F_{i .-j .}$ & 2. $\mathrm{F}_{0.05 ; 2 ; 290}$ & Keputusan \\
\hline TGT dengan TAI & $\mu_{1 .}=\mu_{2 .}$ & 13.7259 & 6 & Ho ditolak \\
\hline TGT dengan Langsung & $\mu_{1 .}=\mu_{3 .}$ & 52.6730 & 6 & Ho ditolak \\
\hline TAI dengan Langsung & $\mu_{2 .}=\mu_{3 .}$ & 12.6884 & 6 & Ho ditolak \\
\hline Berdasarkan Tabel & 1 dan Tabel & 3, maka dapat disimpulkan: & (1) siswa yang
\end{tabular}

mendapat pembelajaran kooperatif tipe TGT mempunyai prestasi belajar yang berbeda dengan siswa yang mendapat pembelajaran koopeartif tipe TAI. Dari rerata marginal antar baris disimpulkan prestasi siswa yang mendapat pembelajaran kooperatif tipe TGT lebih baik daripada rerata prestasi siswa yang mendapat pembelajaran kooperatif tipe TAI. (2) siswa yang mendapat pembelajaran koperatif tipe TGT mempunyai prestasi belajar yang berbeda dengan siswa yang mendapat pembelajaran langsung. Dari rerata 
marginal antar baris disimpulkan prestasi siswa yang mendapat pembelajaran kooperatif tipe TGT lebih baik daripada rerata prestasi siswa yang mendapat pembelajaran langsung, (3) siswa yang mendapat pembelajaran kooperatif tipe TAI mempunyai prestasi belajar yang berbeda dengan siswa yang mendapat pembelajaran kooperatif tipe langsung. Dari rerata marginal antar baris disimpulkan prestasi siswa yang mendapat pembelajaran kooperatif tipe TAI lebih baik daripada rerata prestasi siswa yang mendapat pembelajaran langsung.

Tabel 4 Hasil Uji Komparasi Ganda Antar Kolom

\begin{tabular}{ccccc}
\hline Komparasi & $H_{0}$ & $\mathrm{~F}_{. i-. j}$ & 2. $F_{0.05 ; 2 ; 290}$ & Keputusan \\
\hline Tinggi dengan Sedang & $\mu_{.1}=\mu_{.2}$ & 6.8083 & 6 & $\mathrm{H}_{\mathrm{o}}$ ditolak \\
\hline Tinggi dengan Rendah & $\mu_{.1}=\mu_{.3}$ & 28.2105 & 6 & $\mathrm{H}_{\mathrm{o}}$ ditolak \\
\hline Sedang dengan Rendah & $\mu_{.2}=\mu_{.3}$ & 7.9839 & 6 & $\mathrm{H}_{\mathrm{o}}$ ditolak \\
\hline
\end{tabular}

Berdasarkan Tabel 1 dan Tabel 4, maka dapat disimpulkan: (1) Prestasi belajar matematika pada siswa yang memiliki motivasi berprestasi tinggi dan siswa yang memiliki motivasi berprestasi sedangada perbedaan. Dengan memperhatikan rerata marginal menunjukkan bahwa siswa yang memiliki motivasi berprestasi tinggi mempunyai prestasi belajar matematika lebih baik dibanding dengan siswa yang memiliki motivasi berprestasi sedang. (2) Prestasi belajar matematika pada siswa yang memiliki motivasi berprestasi tinggi dan siswa yang memiliki motivasi berprestasi rendahada perbedaan. Dengan memperhatikan rerata marginal kolom pertama menunjukkan bahwa siswa yang memiliki motivasi berprestasi tinggi mempunyai prestasi belajar matematika lebih baik dibanding dengan siswa yang memiliki motivasi berprestasirendah. (3) Prestasi belajar matematika pada siswa yang memiliki motivasi berprestasi sedang dan siswa yang memiliki motivasi berprestasi rendahada perbedaan. Dengan memperhatikan rerata marginal kolom kedua menunjukkan bahwa siswa yang memiliki motivasi berprestasi sedangmempunyai prestasi belajar matematika lebih baik dibanding dengan siswa yang memiliki motivasi berprestasirendah.

Kesimpulan tersebut sesuai dengan pendapat Suyadi (2013:77) yang menyatakan bahwa melalui pembelajaran kooperatif materi yang dipelajari peserta didik tidak lagi tergantung sepenuhnya kepada guru, tetapi dapat menambah kepercayaan kemampuan berpikir sendiri (mandiri), menggali informasi dari berbagai sumber (rasa ingin tahu), dan belajar dari peserta didik lain. Prestasi siswa yang mendapat pembelajaran kooperatif tipe TGT lebih baik daripada prestasi siswa yang mendapat pembelajaran langsung. Hal ini relevan dengan hasil penelitian yang telah dilakukan Latifa Mustofa Listyanto (2010) yang menyatakan pembelajaran melalui model kooperatif tipe TGT menghasilkan 
prestasi belajar matematika yang lebih baik jika dibandingkan dengan model pembelajaran konvensional.

Dari hasil uji analisis variansi pada Tabel $2, \mathrm{H}_{\mathrm{OB}}$ ditolak artinya terdapat perbedaan rerata prestasi belajar matematika antara siswa dengan motivasi berprestasi tinggi, sedang dan rendah. Untuk mengetahui siswa dengan motivasi berprestasi mana yang memiliki perbedaan maka perlu dilakukan uji lanjut pasca anava atau uji komparasi ganda antar kolom. Berdasarkan Tabel 1 dan Tabel 4, maka dapat disimpulkan: (1) siswa dengan motivasi berprestasi tinggi mempunyai prestasi yang lebih baik daripada siswa dengan motivasi berprestasi sedang, (2) siswa dengan motivasi berprestasi tinggi mempunyai prestasi yang lebih baik daripada siswa dengan motivasi berprestasi rendah, (3) siswa dengan motivasi berprestasi sedang mempunyai prestasi yang lebih baik daripada prestasi belajar siswa dengan motivasi berprestasi rendah.

Hasil penelitian ini menyatakan siswa dengan motivasi berprestasi tinggi mempunyai prestasi belajar yang berbeda dengan siswa motivasi berprestasi sedang. Siswa dengan motivasi berprestasi tinggi mempunyai prestasi belajar yang lebih baik dibandingkan siswa dengan motivasi berprestasi rendah. Siswa dengan motivasi berprestasi sedang mempunyai prestasi belajar yang beerbeda dibandingkan siswa dengan motivasi berprestasi rendah.

Berdasarkan kajian teori hasil penelitian ini sesuai dengan pendapat Murray dalam Beck (1990: 279) motivasi berprestasi adalah kebutuhan atau hasrat untuk mengatasi kendala-kendala, menggunakan kekuatan, berusaha melakukan sesuatu yang sukar, sebaik dan secepat mungkin. Kebutuhan untuk berprestasi bagi siswa bersifat intrinsik, siswa yang mempunyai motivasi berprestasi tinggi ingin menyelesaikan tugastugas dan meningkatkan penampilannya. Siswa ini berorientasi pada tugas-tugas dan masalah-masalah yang memberikan tantangan, di mana penampilannya dapat dinilai dan dibandingkan dengan patokan penampilan orang lain.

Hasil penelitian ini sesuai dengan hasil penelitian Umar Hadianto (2009) yaitu: prestasi belajar siswa yang mempunyai tingkat motivasi berprestasi tinggi lebih baik daripada siswa yang mempunyai tingkat motivasi berprestasi sedang maupun rendah, dan prestasi belajar siswa yang mempunyai tingkat motivasi berprestasi sedang lebih baik daripada siswa yang mempunyai tingkat motivasi berprestasi rendah.

Dari hasil analisis variansi yang telah dilakukan diperoleh hasil $\mathrm{H}_{O A B}$ diterima. Hal ini berarti tidak terdapat interaksi antara model pembelajaran dengan motivasi berprestasi terhadap prestasi belajar matematika siswa pada materi bangun ruang sisi datar sehingga tidak perlu dilakukan uji lanjut pasca anava antar sel pada kolom yang 
sama. Dari hasil uji hipotesis tersebut dapat disimpulkan bahwa tidak terdapat interaksi ini dapat disimpulkan bahwa model pembelajaran kooperatif tipe TGT, TAI dan pembelajaran langsung tidak berpengaruh pada prestasi belajar matematika materi pokok bangun ruang sisi datar dengan apabila ditinjau dari motivasi berprestasi siswa.

Berdasarkan hasil pada uji komparasi ganda antar baris, siswa yang mendapat pembelajaran kooperatif tipe TGT mempunyai prestasi belajar yang lebih baik dari pada siswa yang mendapat pembelajaran kooperatif tipe TAI, siswa yang mendapat pembelajaran koopeartif tipe TGT mempunyai prestasi lebih baik daripada siswa yang mendapat pembelajaran langsung, dan siswa yang mendapat pembelajaran kooperatif tipe TAI mempunyai prestasi yang lebih baik daripada siswa yang mendapat pembelajaran kooperatif tipe langsung. Karena tidak terdapat interaksi, maka kesimpulan tersebut juga berlaku pada tiap-tiap motivasi berprestasi.

Hasil penelitian ini berbeda dengan penelitian yang dilakukan oleh Syahrir (2011) yaitu nilai siswa yang mendapatkan pembelajaran kooperatif tipe TGT mempunyai prestasi belajar yang lebih baik dari pada siswa yang mendapatkan model pembelajaran kooperatif tipe jigsaw. Kaitan yang diperoleh dari hipotesis yang ketiga ini tidak sesuai dengan hipotesis penelitian yang menyatakan pada siswa dengan motivasi berprestasi tinggi yang mendapat pembelajaran dengan menggunakan pembelajaran kooperatif tipe TGT lebih baik prestasi belajar matematikanya daripada siswa yang mendapat pembelajaran dengan menggunakan pembelajaran kooperatif tipe TAI. Pada siswa dengan motivasi berprestasi sedang yang mendapat pembelajaran dengan menggunakan pembelajaran kooperatif tipe TGT lebih baik prestasi belajar matematikanya daripada siswa yang mendapat pembelajaran dengan menggunakan pembelajaran kooperatif tipe TAI. Pada siswa dengan motivasi berprestasi rendah yang mendapat pembelajaran dengan menggunakan pembelajaran kooperatif tipe TAI lebih baik prestasi belajar matematikanya daripada siswa yang mendapat pembelajaran dengan menggunakan pembelajaran kooperatif tipe TGT.

Tidak terdapat interaksi antara model pembelajaran dan motivasi berprestasi terhadap prestasi belajar matematika siswa mungkin dikarenakan dalam mengikuti pelajaran siswa kurang memperhatikan terhadap materi yang disampaikan serta adanya variabel bebas yang lain yang karena keterbatasan peneliti tidak termasuk dalam penelitian ini, misalnya bimbingan belajar yang diikuti siswa, kedisipilinan belajar siswa ketika di rumah, latar belakang keluarga dan lingkungan, serta faktor-faktor lainnya.

Kegiatan penelitian pada uji hipotesis ketiga tidak teruji, hal ini disebabkan beberapa faktor antara lain; (1) Ada kemungkinan karena peneliti tidak dapat mengontrol 
faktor luaran yang terjadi selama penelitian dilakukan, misalnya masalah kesehatan, motivasi yang meningkat maupun yang menurun dan sebagainya; (2) Dalam pembelajaran peneliti belum tepat dalam menerapkan langkah-langkah dari kedua model pembelajaran tersebut untuk siswa yang mempunyai motivasi berprestasi sedang dan rendah, sehingga dalam pelaksanaan pembelajaran di kelas belum terlihat perbedaan yang signifikan; (3) Siswa yang mempunyai motivasi berprestasi sedang dan rendah belum siap untuk mempelajari sendiri materi ajar yang diberikan; (4) Siswa yang mempunyai motivasi berpretasi sedang dan rendah masih perlu bimbingan yang lebih dari guru.

\section{SIMPULAN DAN SARAN}

Berdasarkan hasil penelitian ini maka dapat disimpulkan: (1) Siswa yang mendapat pembelajaran kooperatif tipe TGT mempunyai prestasi belajar yang lebih baik daripada siswa yang mendapat pembelajaran kooperatif tipe TAI dan pembelajaran langsung, dan siswa yang mendapat pembelajaran kooperatif tipe TAI mempunyai prestasi yang lebih baik daripada siswa yang mendapat pembelajaran langsung; (2) Siswa dengan motivasi berprestasi tinggi mempunyai prestasi yang lebih baik daripada siswa dengan siswa dengan motivasi sedang dan motivasi berprestasi rendah. Dan prestasi belajar siswa dengan motivasi berprestasi sedang mempunyai prestasi yang lebih baik daripada siswa yang mempunyai motivasi berprestasi rendah; (3) Pada tiap-tiap jenis model pembelajaran menunjukkan bahwa prestasi belajar siswa dengan motivasi berprestasi tinggi mempunyai prestasi yang lebih baik daripada siswa dengan motivasi berprestasi sedang dan motivasi berprestasi rendah, siswa dengan motivasi berprestasi sedang mempunyai prestasi yang lebih baik daripada siswa dengan motivasi berprestasi rendah; (4) Pada masing-masing jenis motivasi berprestasi menunjukkan bahwa siswa yang mendapat pembelajaran kooperatif tipe TGT mempunyai prestasi belajar yang lebih baik daripada siswa yang mendapat pembelajaran kooperatif TAI dan pembelajaran langsung, prestasi siswa yang mendapat pembelajaran kooperatif tipe TAI lebih baik daripada prestasi siswa yang mendapat pembelajaran langsung.

Berdasarkan kesimpulan di atas makan penulis sampaikan beberapa saran agar prestasi belajar matematika pada umumnya dan materi dasar bangun ruang sisi datar pada khususnya dapat ditingkatkan, maka disarankan: (1) Sebaiknya seorang guru matematika sudah mulai menggunakan model pembelajaran kooperatif di dalam proses belajar mengajarnya misalnya model pembelajaran kooperatif tipe TGT atau TAI sehingga membuat siswa aktif didalam proses pembelajaran yang akhirnya prestasi belajarnya dapat meningkat secara maksimal; (2) Sebaiknya guru mengetahui berbagai macam tipe model pembelajaran kooperatif sehingga dapat menerapkannya dalam penyampaian 
materi yang sesuai; (3) Dalam memilih model pembelajaran hendaknya guru memperhatikan faktor-faktor yang mempengaruhi proses dan hasil belajar siswa. Salah satu diantaranya adalah dengan memperhatikan motivasi berprestasi yang dimiliki siswa sehingga dalam proses pembelajaran akan diperoleh hasil yang maksimal; (4) Sebaiknya para siswa melakukan persiapan belajar lebih baik dalam mengikuti pembelajaran matematika baik menggunakan model kooperatif tipe TGT maupun TAI; (5) Sebaiknya para siswa selalu aktif berdiskusi dalam kelompok sehingga mampu meningkatkan prestasi belajar; (6) Sebaiknya kepala sekolah menghimbau para guru untuk mulai menerapkan model pembelajaran kooperatif tipe TGT atau TAI di dalam proses pembelajarannya sehingga hasil belajar yang diperoleh siswa menjadi lebih baik; (7) Memberi dukungan sepenuhnya kepada para guru dengan menyediakan berbagai fasilitas yang dibutuhkan sehingga dapat menunjang terlaksananya proses belajar mengajar dengan menggunakan model pembelajaran kooperatif tipe TGT maupun model kooperatif tipe TAI; (8) Penelitian ini mungkin dapat dijadikan sebagai perbandingan untuk penelitian selanjutnya karena hanya terbatas pada materi bangun ruang sisi datar. Oleh karena itu, dimungkinkan untuk dilakukan penelitian pada pokok bahasan yang lain; (9) Sebaiknya para peneliti dapat mengembangkan penelitian untuk variabel lain yang banyak jumlahnya yang masih bayak jumlahnya, seperti model pembelajran problem possing, RME, inquiry, dan lain sebagainya untuk meningkatkan prestasi belajar matematika siswa, sehingga dapat menambah wawasan dan kualitas pendidikan yang lebih baik, khususnya pendidikan matematika.

\section{DAFTAR PUSTAKA}

Arends, R.I. 2008. Learning To Teach. Edisi ketujuh. Yogyakarta: Pustaka Belajar.

Degeng, I.N.S. 1997. Strategi Pembelajaran, Mengorganisasi Isi dengan Model Elaborasi. Malang: IKIP Malang bekerja sama dengan Biro Penerbitan Ikatan Profesi Teknologi Pendidikan.

Gisbert, N. M., David, J., \& Carles, R. 2008. The Impact of Peer Tutoring on The Improvement of Linguistic Competence, Self-Concept as a Writer and pedagogical Satisfaction, School Psychology International (2008), Vol 29(4) 481-499.

Ngalim Purwanto.1990. Psikologi Pendidikan. Bandung: PT Remaja Rosdakarya.

Nurhadi. 2004. Kurikulum 2004. Jakarta: Gramedia

Sardiman. 2001. Interaksi \& Motivasi Belajar Mengajar. Jakarta : Raja Grafindo Persada. 
Shefali, P. 2011. Interactive Of Cooperative Learning Model and Goals Of Students On Academic Achievement Of Students In Mathematics. Mevlana International Journal of Education (MIJE). 1(2). Pp 82-94 Diakses 17 Januari 2013.

Slavin, E. 2008. Cooperative Learning: Teori, Riset dan Praktek. Penerjemahan: Nurulita Yusron. Bandung : Nusa Media.

Shimazoe, J and Aldrich, H. 2010. Group Work Can Be Gratifying : Understanding \& Overcoming Resitence To Cooperative Learning. Journal of College Teaching. Vol. 58. No. 1 pp. 52-57.

Suyadi. 2013. Strategi Pembelajaran Pendidikan Karakter. Bandung: Remaja Rosdakarya

Syahrir. 2011. Effects of The Jigsaw and Teams Games Tournament Cooperative Learning On The Learning Motivation and Mathematical Skill Of Junior High School Students. Journal Departement of Mathematic Education Teacher Training Collage Of Mataram. No. 4. pp 154-168.

Umar Hadianto. 2009. Efektivitas Pembelajaran Kooperatif Dengan Group Investigation Terhadap Prestasi Belajar Matematika Ditinjau Dari Motivasi Berprestasi. Tesis:UNS Surakarta 